\title{
Seasonal Variability of Water Quality and Nutrient Removal Efficiency of a Restored Wetland
}

\author{
Kunan Brewer Vesselly ${ }^{(1)^{*}}$, Alfonse Opio ${ }^{(2)}$, Majaliwa Mwanjalolo ${ }^{(3)}$, \\ Frank Kansiime ${ }^{(4)}$ \\ ${ }^{(1)}$ South China Agricultural University \\ ${ }^{(2)}$ Faculty of Science, Gulu University \\ ${ }^{(3)}$ Department of Geo-Informatics and Climate Sciences, Makerere University \\ ${ }^{(4)}$ Department of Environmental Management, Makerere University
}

Received: 19 September 2020

Accepted: 21 November 2020

Published online: 31 December 2020

\begin{abstract}
Most studies of wetlands in Uganda use for water and wastewater treatment have focused on natural undisturbed pristine wetland and constructed wetlands. There exists a gap in literature surrounding treatment abilities of restored wetland or wetlands on a path to recovery. Water quality parameters were sampled covering wet and dry seasons in a restored wetland. Soil properties were also assessed and compared with a referenced natural site. The objectives of the study were to (i) determine the effects of wetland restoration on nutrient retention and release, (ii) analyze temporal dynamics of water quality parameters in the restored wetland, and (iii) describe soil properties in depths of the restored wetland in relation to a reference natural site. Values of $\mathrm{pH}$, electrical conductivity (EC), temperature, total dissolved solids (TDS), TN and NO3-N showed significant differences across seasons. The wetland demonstrated little water quality benefits but the overall nutrient removal efficiency when compared to literature values was found to be not impressive. Rates for P and N removal were between $3.5-19 \%$ and -10.8 $-32.4 \%$ respectively. These results could be attributed to flooding, low residence time of the water, small size of the wetland, low influent load, extra nutrient inputs from fertilizers and pollution sources as well as release from soil. We recommended that management activities like harvesting; redesigning the channels for water distribution throughout the system and removal of invasive plant species be carried out. This study will form a baseline in understanding the ecology of restored wetlands in Uganda.
\end{abstract}

Keywords: wetlands, Restoration, water quality, nitrogen, phosphorus

\section{Introduction}

Wetlands ecosystems are amongst the most important providing provisioning, regulating, supporting and cultural services globally (Millennium Ecosystem Assessment 2005; Mitsch and Gosselink 2015). Provisioning services include fisheries support and direct food production. Regulating

* Corresponding author: Kunan Brewer Vesselly

e-mail: kbvesselly@gmail.com 
Kunan Brewer Vesselly et al.

services include improving water quality, protecting coastlines from natural disasters promoting carbon sequestration, and protecting the habitat of rare and endangered species. Cultural services are involved with various activities linked to this specific landscape, i.e., ecology education, ecotourism, birdwatching, etc (Mitsch et al. 2015). Wetland degradation, linked to anthropogenic pressures and climate change is a major global problem. Despite concerted efforts to restore natural wetlands for human wellbeing, global change and intense anthropogenic pressure have destroyed more than half of global wetlands during the last century (Wang et al. 2012; Davidson 2014).

To regain services provided by wetlands, management agencies are increasingly turning to wetland restoration (Mitsch et al. 2001; Zedler 2003). Wetlands restoration is a systematic process (Kirk et al. 2004). Typically, wetlands restoration focuses on restoring three key components: hydrology, biology and soil of wetlands. Investigation of these components in restored ecosystems and how they change during ecosystem development is a necessary research area and has therefore received a great deal of research attention in recent years (Lu 2008; McCauley et al. 2013).

Wetland hydrology is often considered as the most critical component to wetland restoration success (Kusler and Kentula 1990). Water is an important component of wetland hydrology (Effendi 2016) and water quality is an indicator of water's suitability for maintaining various industrial applications and processes, as well as a potential factor in supporting biodiversity and ecosystem function (Khan et al. 2015; Duan et al. 2016). Water quality is generally expressed as the concentration of inorganic and organic materials in the water, and its degradation can seriously affect wetland ecosystems function (Duan et al. 2016; Jiang et al. 2015). Like hydrology, the restoration of wetland soil properties is another important factor in restoration, as soils are the physical foundation of wetland ecosystems (Stolt et al. 2000).

Wetlands in Uganda have come under considerable pressure and most of them are on the brink of total degradation due to the uneven nature of activities affecting them. Nowhere is this more evident than in the wetlands that surround the world's largest tropical lake, Lake Victoria, where a growing population and developing economy continue to put pressure on these vital ecosystems which are relied upon to attenuate industrial, urban and agricultural pollution and supply numerous services and resources (Kansiime et al. 2007). Uganda has an area of 241,550.7 square kilo kilometers (sq.km), of which 41,027.4 sq km are open water bodies and wetlands while 200,523.2 sq km is land (UBOS 2014).

In Uganda, the National Environment Management Authority (NEMA) and the Wetland Management Department of the Ministry of Water and Environment institute penalties that range from levying fines to ordering the restoration of wetlands that are degraded severely by encroachment. This was the case with an urban wetland, Nakyesanja, in Uganda's Wakiso district that was ordered restored by NEMA to be carried out by the encroacher - the Kawanda Secondary School. The School had encroached on the wetland to create playground for its students. The main goal of the restoration was to reverse the impacts of the disturbance by reinstating wetland hydrology and planting obligate and facultative wetland plants (Zedler 2003; Verhoeven et al. 2006); in this case the predominant plant was Cyperus papyrus $\mathrm{L}$.

A review of literature found gaps in the ecology of restored wetland systems in Uganda as most studies focus on natural and constructed wetlands use for wastewater treatment. Our main objectives were to: (i) determine the effects of wetland restoration on nutrient retention and release, (ii) analyze temporal dynamics of water quality parameters in the restored wetland, and (iii) describe soil properties in depths of the restored wetland in relation to a reference natural site. On a larger scale, the results and restoration processes highlighted herein could be used to foster wetland conservation efforts in Uganda and beyond. 
Kunan Brewer Vesselly et al.

\section{Materials and Methods}

\section{Study Areas}

The studied wetland is located in Wakiso District adjacent the Kawanda Research Center along the Kampala-Gulu highway in Uganda (Fig. 1.). The restored wetland, Nakyesanja, lies directly opposite Kawanda Secondary School in Nabweru sub-County at the following coordinates $32^{\circ} 32^{\prime}$ $3.066^{\prime}$ ' N; $0^{\circ} 24$ ' 14.7132' $E$. The estimated terrain elevation above sea level for Nakyesanja wetland is 1160 meters. The estimated size of this wetland is 0.4 hectares and was restored in 2009. Soil samples were also collected from a referenced natural wetland, Kiryagonja, located in Gombe sub-County. The referenced natural wetland was located at the following coordinates: $32^{\circ} 29^{\prime} 33.126^{\prime}$ ' N; 0 $30^{\prime}$ '54.5184', E with an estimated terrain elevation above sea level of 1150 meters.

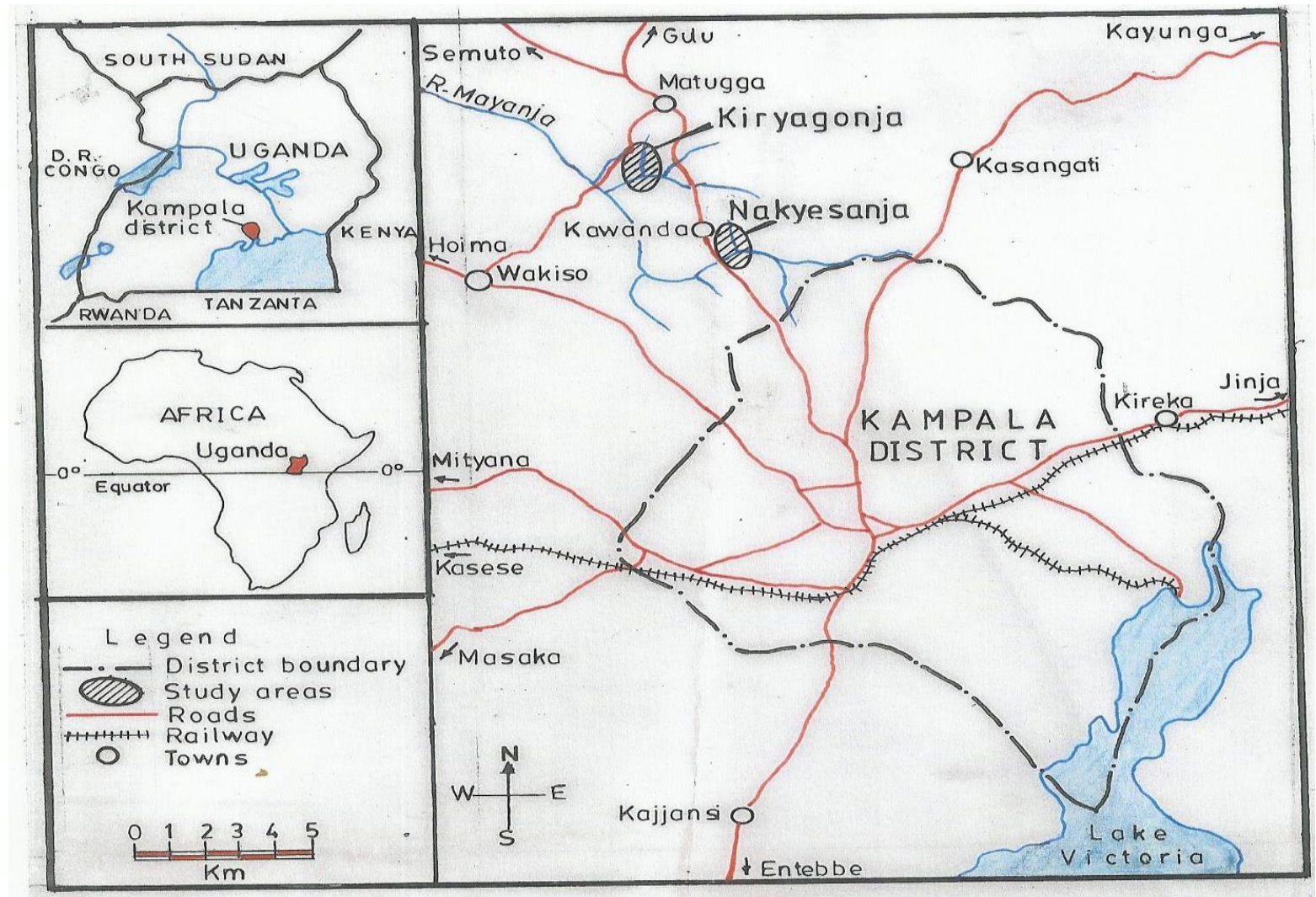

Fig. 1. Map of the Study Areas showing the location of Nakyesanja and Kiryagonja Wetlands.

\section{Water Sampling Procedure and Chemical Analysis}

Water samples were collected from two sites in the restored wetland only so as to establish whether the quality of water improved as the water flows through the wetland. Samples were taken at the inflow into the wetland and at the outflow from the wetland. Sampling was done covering wet and dry seasons. For the wet season, water sampling was done from the beginning of October to early December 2014, and data for the dry season was captured from Mid-December 2014 to late February 2015. Each sampling period covered 10 weeks $\times 2$ sites $\times 2$ seasons making a total of 40 samples. Samples were collected in a $500 \mathrm{ml}$ plastic bottle labeled with the date and site number. The sample bottles were placed in a cool box and transported to the laboratory for analysis. The flow rate was also determined in situ by using a 20 liter bucket and a stopwatch. The load of every nutrient was calculated at the inflow and outflow by multiplying the concentration by the flow rate. After which the efficiency 
Kunan Brewer Vesselly et al.

of nutrient removal was calculated using the formula: (Load Inflow - Load Outflow) / Load Inflow * $100 \%$. Net nutrient flux was simply computed as inputs minus exports of a given concentration per day.

The following parameters were measured in situ: $\mathrm{pH}$, electrical conductivity, total dissolved solids (TDS), and temperature using a Hanna Waterproof meter HI 98129. The other parameters including total phosphorus (TP), total nitrogen (TN), ammonium-nitrogen $\left(\mathrm{NH}_{4}-\mathrm{N}\right)$, nitrate-nitrogen $\left(\mathrm{NO}_{3}-\mathrm{N}\right)$ and soluble reactive phosphorus (SRP) were analyzed in the laboratory according to American Public Health Association's (APHA) standard methods for the examination of water and wastewater (APHA 1998). Ammonium-nitrogen was determined by titration using Nessler's reagent. Nitrate was determined using Devarda's alloy method. Soluble reactive phosphorus was determined using the ascorbic acid method in a Phenolphthalein indicator solution. Total nitrogen and total phosphorus were determined using the Persulfate digestion method by adding persulfate solution and placing in an oven for one hour at a temperature of $105^{\circ} \mathrm{C}$.

\section{Soil Sampling}

Soil samples were collected from the same depths in both restored and a referenced natural site using an auger. The depths collected were: $0-10 \mathrm{~cm}, 10-30 \mathrm{~cm}$ and $30-60 \mathrm{~cm}$. Soil samples were taken once to understand the concentration of soil properties and their influence on water quality changes. Approximately one kilogram of sub-sample from each soil depth was taken and put into plastic bags, air-dried to constant weight at room temperature, crushed, homogenized, and passed through a $2 \mathrm{~mm}$ sieve before laboratory analysis. Soil colour and texture were determined in situ. Soil colour was determined using Munsell Standard Color Charts (Munsell Color Chart, 1994).The textural classes of soil were named using FAO Guidelines for Soil Description (Jahn et al. 2006).

\section{Laboratory analyses of soil properties}

The following variables were analyzed in the Soil Science Laboratory at Makerere University: $\mathrm{pH}$, conductivity, organic matter, calcium, nitrogen, available phosphorus and potassium. These parameters were analyzed using methods described by Okalebo et al. (2002). Calcium and Potassium in the soil were analyzed using the Flame photometer on an ammonium acetate extract. Phosphorus was determined using a spectrophotometer using Murphy Riley Molybdenum blue method at a wavelength of $880 \mathrm{~nm}$. Soil $\mathrm{pH}$ and electrical conductivity were measured in a soil-water solution at a ratio of 1:2.5 using $\mathrm{pH}$ and conductivity meters respectively; Total nitrogen $(\mathrm{N})$ was determined calorimetrically following digestion; and Organic matter $(\mathrm{OM})$ was determined using Black and Walkly oxidation method. Soil Organic carbon was determined as a percentage of organic matter by dividing organic matter by 1.72 (Landon 1991).

\section{Statistical Analysis}

To examine differences in water chemistry in seasons and between sites we used analaysis of variance (ANOVA). In some instances data were log-transformed to meet assumptions of normality. All statistics were computed at a 95 percent confidence level $(\mathrm{p} \leq 0.05)$.

Soil results were interpreted using their associated ratings from Booker Tropical Soil Manual (Landon 1991) and Okalebo et al. (2002). The interpretations described variation by looking at the ranges of each soil property in the different depths of the restored and referenced natural wetlands. 
Kunan Brewer Vesselly et al.

\section{Results}

\section{Temporal variation in water quality parameters}

The results of this study reveal significant temporal variance of $\mathrm{pH}$, Discharge, Electrical Conductivity (EC), Temperature and Total Dissolved Solids (TDS) (Tab. 1). All the water samples considered here were alkaline ( $\mathrm{pH}$ values between $7.3-7.8$ ). Results show that the $\mathrm{pH}$ value recorded in dry was higher than that of the wet season. EC recorded significant higher value in the wet season in comparison to the dry season. The value of temperature though significant higher in the dry season fell with the standards for effluent discharge in Uganda. Similarly, TDS value fell below standards for effluent discharge in Uganda (1200 mg/l) and was significantly higher in the wet season.

Tab. 1. Difference in Mean values \pm standard error of water quality parameters during the dry and wet season and their respective $\mathrm{p}$ values $(\mathrm{n}=40)$.

\begin{tabular}{llll}
\hline Parameters & Dry Season & Wet Season & P-Value \\
\hline $\mathrm{pH}$ & $7.6 \pm 0.021$ & $7.7 \pm 0.027$ & 0.016 \\
Discharge $(\mathrm{l} / \mathrm{s})$ & $0.86 \pm 0.05$ & $3.62 \pm 0.23$ & $<0.001$ \\
$\mathrm{EC}(\mu \mathrm{S} / \mathrm{cm})$ & $246.1 \pm 4.8$ & $309 \pm 4.4$ & $<0.001$ \\
Temperature $\left({ }^{\circ} \mathrm{C}\right)$ & $22.52 \pm 0.32$ & $21.6 \pm 0.29$ & 0.043 \\
Total Dissolved Solids $(\mathrm{mg} / \mathrm{l})$ & $122.9 \pm 2.39$ & $154.4 \pm 2.23$ & $<0.001$ \\
\hline
\end{tabular}

\section{Nutrient Removal Rates and Nutrient Flux Balance}

The data assembled in this study show that nutrient removal rates varied over both seasons (Tab. 2). Particularly, during the dry season $\mathrm{N}$ removal rates ranged from $15.4 \%$ to $19 \%$ and from $0 \%$ to $9.5 \%$ in the wet season depending on types and inflow loading. Recorded $\mathrm{P}$ removal rates ranged from $26 \%$ to $32.4 \%$ in the dry season and $-10.8 \%$ to $2.8 \%$ in the wet depending on different types and inflow loading.

Tab. 2. Nutrient removal rates of different seasons in the restored wetland.

\begin{tabular}{llll}
\hline Parameters & Season & Load Outlet (kg / day) & Removal Rate \\
\hline $\mathbf{N}$ & Dry & $2.97 \times 10^{-4}$ & $15.4-19 \%$ \\
& Wet & $1.57 \times 10^{-3}$ & $0-9.5 \% \%$ \\
$\mathbf{P}$ & Dry & $7.7 \times 10^{-4}$ & $26-32.4 \%$ \\
& Wet & $3.29 \times 10^{-3}$ & $-10.8-2.8 \%$ \\
\hline
\end{tabular}

The figures (Fig. 2A - 2E) display the net nutrient flux of TN, $\mathrm{NH}_{4}-\mathrm{N}, \mathrm{NO}_{3}-\mathrm{N}$, TP and SRP. In a case where inputs were greater than exports (positive value), the restored wetland was considered to be retaining the nutrients; but if the given inputs were less than the exports (negative value), it was considered release by the ecosystem. The restored wetland was predominantly a sink of TN in the dry season as the inputs was larger than the exports for most of the dry season. The wetland was not retentive of TN during the wet season as the wetland kept changing from a source to a sink but the overall release was more. It was a similar pattern observed for $\mathrm{NH}_{4}-\mathrm{N}$ for both dry and wet seasons. Inputs were higher than exports for $\mathrm{NO}_{3}-\mathrm{N}$ in the dry and the restored wetland release $\mathrm{NO}_{3}-\mathrm{N}$ throughout the wet season. Even though the wetland fluctuated between being a source and sink for TP during the dry, the retention was relatively higher than the wet. Net fluxes for SRP were retained in the early and late dry season. Huge release of SRP was observed in the early wet season but there was an improvement as the season progressed. 
Kunan Brewer Vesselly et al.

\section{Relationship between Temperature and Water Quality Parameters}

Figure $\mathrm{F}$ displays the linear regression between temperature and $\mathrm{NO}_{3}-\mathrm{N}$ in the restored wetland. There was a strong and positive correlation $(\mathrm{R}=0.94 ; \mathrm{p}<0.05)$ observed between temperature and $\mathrm{NO}_{3}-\mathrm{N}$. The relationships between temperature and other water quality nutrients were not significant.
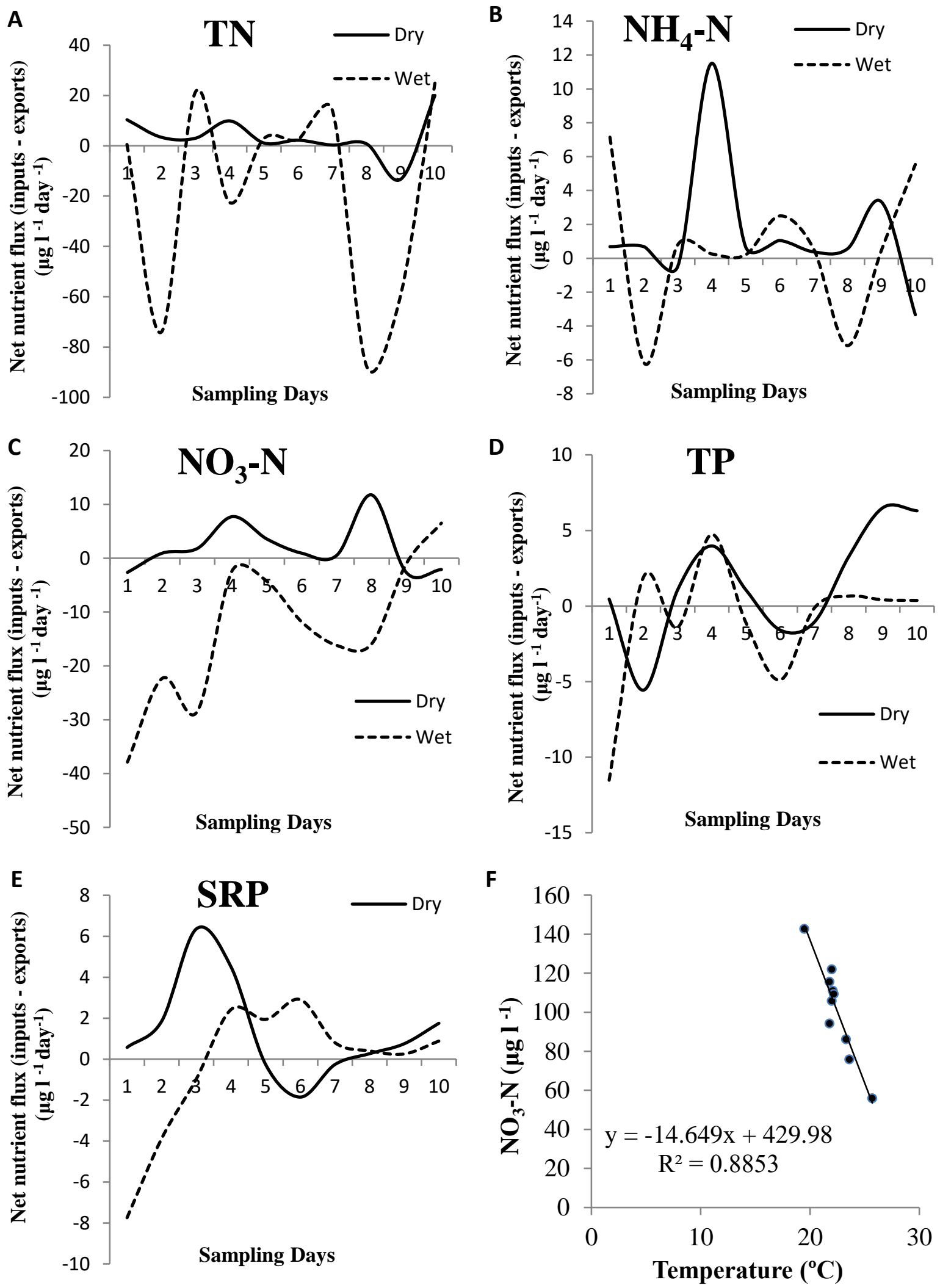

Fig. 2A - 2F. The net nutrient flux of TN, $\mathrm{NH}_{4}-\mathrm{N}, \mathrm{NO}_{3}-\mathrm{N}$, TP and SRP. 


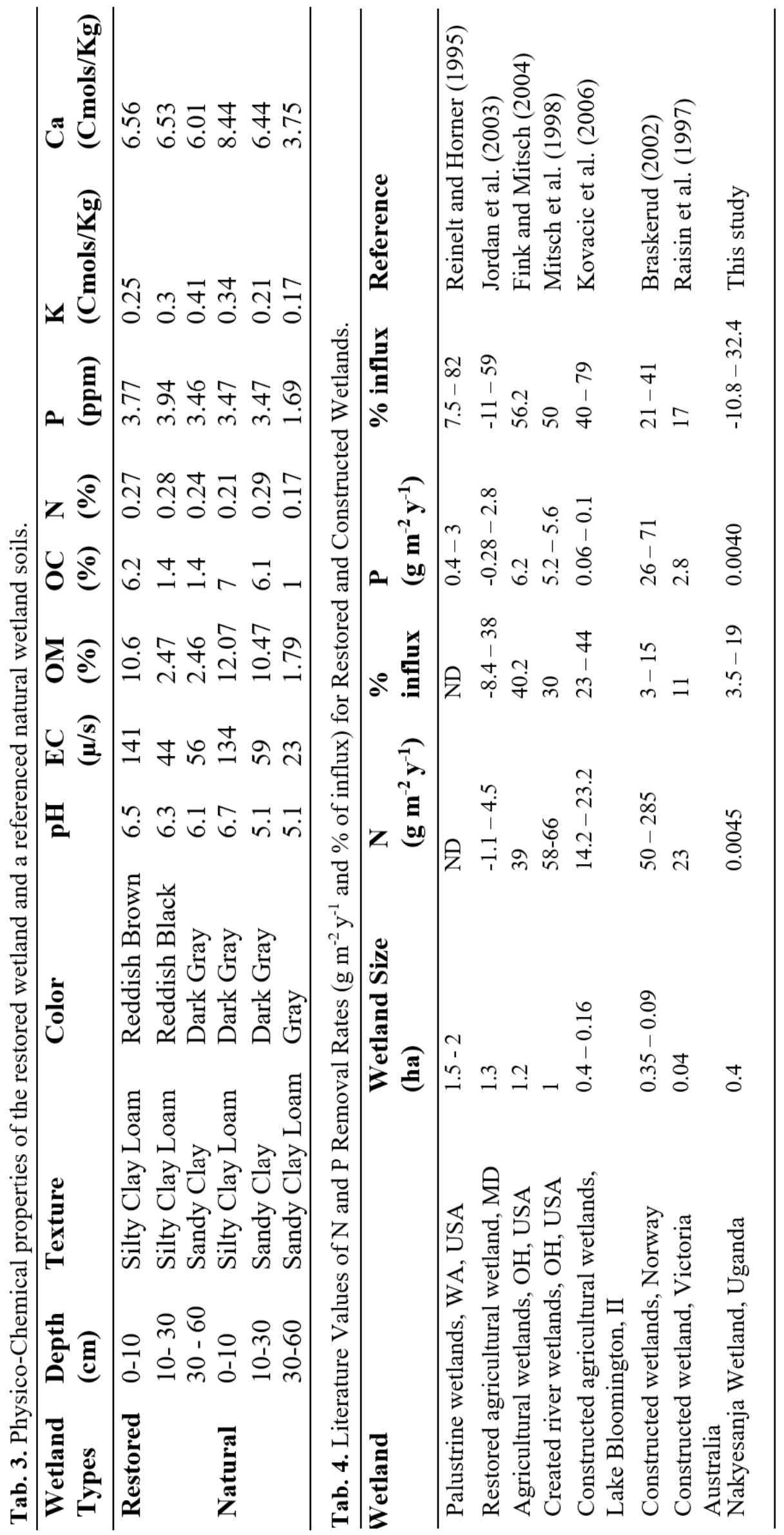




\section{Soil properties in the restored and referenced natural wetlands}

Physico-Chemical properties of the restored and a referenced natural wetland soils are presented in Table 3 . The $\mathrm{pH}$ of the restored wetland was slightly alkaline and did not vary widely across the layers. In the natural wetland $\mathrm{pH}$ reduces drastically with depths (becoming acidic). Soil organic matter tended to decrease with depth in both wetlands. Though the natural wetland had relatively higher organic matter in the top layer than the restored wetland, OM fell within the same range. The top layer of the restored wetland had relatively higher concentration of Nitrogen $(\mathrm{N})(0.27 \%)$ than the top layer of the natural wetland $(0.21 \%)$. There was relatively higher concentration of Phosphorus $(\mathrm{P})$ in the top and sub-surface layers of the restored wetland than the natural wetland. $\mathrm{P}$ was increasing with depth in the restored while it was constant in the first two layers in the natural wetland. There was an opposite trend observe for Potassium (K) in the wetlands. With a relatively higher concentration in the top layer of the natural wetland, $\mathrm{K}$ was decreasing with depth. $\mathrm{K}$ was increasing with depths in the restored wetland. There was relatively lesser concentration of Calcium $(\mathrm{Ca})$ in the top layer of the restored wetland in comparison to the natural wetland.

\section{Discussion}

\section{Temporal variability in water quality parameters}

The $\mathrm{pH}$ is one of the most important indicators of water quality in aquatic ecosystems (Khan et al. 2013; Wang et al. 2017). All of the samples analyzed here fell within the recommended range of $\mathrm{pH}$ values, between $\mathrm{pH} 6.5$ and $\mathrm{pH} 8.5$ (World Health Organization 2001) as Uganda has aligned its water standards to international standards (UNBOS 2019). The water $\mathrm{pH}$ was higher than $\mathrm{pH}$ value $(6.6-6.8)$ reported for constructed wetland planted with papyrus (Kyambadde et al. 2004) probably because of the presence of less humus and an increase in algae photosynthesis which led to the production of more hydroxyl. The shallow water depth, open canopy and the motionless water surface of the restored wetland acted to increase water temperatures in the warmer months. The high EC level in the rainy months could be associated with polluted runoffs from domestic and industrial sources especially from the Kampala Capital City Authority (KCCA) garbage collection point in Kawanda town. A similar result was also reported by Kansiime et al. (2007) in which they attributed increase in conductivity and attributed that to polluted runoff in their study of pristine and disturbed wetlands in Uganda. The higher TDS in the wet season may be attributed to high surface runoff, erosion, stormwater and urban runoff, the transport of decay plants and animals and bricks making. Another reason could be during the wet season the water was sharply more oxygenated and contain high ion concentration due to higher salinity water seepage (Cabezas et al. 2009).

\section{Restoration Effects - Nitrogen Removal}

The removal rates for $\mathrm{NH}_{4}-\mathrm{N}$ were low $(9.5-19 \%)$ and this could because of the short residence time in the restored wetland and the small size of the wetland which made plant uptake to be negligible. This is in agreement with Moreno et al. (2007) who reported that larger wetlands removed more $\mathrm{N}$ than medium and small ones. The results of this study also suggest that nitrification could have been inhibited in the flooded slightly acidic soil. The removal rates for $\mathrm{NH}_{4}-\mathrm{N}$ were similar to those reported for constructed wetland pilot units in Kirinya wetland (Okurut 1999) which was $<20 \%$. Ammoniumnitrogen struggle to be removed as temperature and $\mathrm{pH}$ were not within the range that could support both nitrification and denitrification processes. The removal rates of $\mathrm{TN}$ range from $0-15.4 \%$ and were lower compared to values reported for constructed wetland ranges (40 - 55\%) by Vymazal (2007). This could be because of the release of nitrogen from surface soil as the soil of the restored wetland was 
Kunan Brewer Vesselly et al.

found higher in nitrogen concentration in comparison to a referenced natural wetland soil. These results are in agreement with Whitehead et al. (2006) and Krause et al. (2008) who showed that the removal of $\mathrm{N}$ declined due to increasing soil release of this element. The removal rates of $\mathrm{NO}_{3}-\mathrm{N}$ were between 3.5 - 18.4\%. These rates were low compared to other natural and restored wetlands (Reddy and Delaune 2008) and the reason is probably because there was low $\mathrm{NO}_{3}-\mathrm{N}$ loading and low temperature to support nitrification as temperature was found to have a positive correlation to $\mathrm{NO}_{3}-\mathrm{N}$ in the restored wetland. But as the plants get mature it is expected that there will be better nitrification-denitrification in the site. The results in this study for $\mathrm{N}$ removal are below those that were obtained by other restored and constructed wetlands with similar sizes (Tab. 4).

\section{Restoration Effects - Phosphorus Removal}

The removal rates for TP ranged from -10.8 to $26 \%$ and 2.8 to 32.4 for SRP respectively. These low removal rates could be attributed to $\mathrm{P}$ release after reflooding and the decrease in redox and subsequent release of Fe-bound $\mathrm{P}$ as well as release of microbial $\mathrm{P}$ (soil data of the site; Aldous et al. 2005; Van Dijk et al. 2004). Flooding may have also cause large quantities of nutrients to flow off the fields, far beyond the removal capacity of the wetland. Flooding in the wetland caused reduced retention of nutrients which was also the case with Mitsch et al. (2005) who showed that SRP retention declined when a 1 hectare restored wetland received pulse water inflow as opposed to more constant flow. Similarly, Fink and Mitsch (2007) also showed decreased P retention due to spring and early summer storms while assessing a 1.2 hectares wetland. Other studies indicated that TP removal ranges between $40 \%$ and $60 \%$ in wetlands, depending on type and inflow loading (Vymazal et al. 2007). Even though there was export of $\mathrm{P}$ observed in the site, the results of $\mathrm{P}$ removal rates show that there was a marginal effect of seasonality on $\mathrm{P}$ removal probably because there was little adsorption of soluble phosphorus to roots and peats during the dry season. The results in this study for P removal are below those that were obtained by other restored and constructed wetlands with similar sizes (Tab. 4).

\section{Restoration Effects - Soil properties}

The organic matter $(\mathrm{OM})$ of the natural wetland was relatively higher than the restored and degraded wetlands. This can be attributed to the waterlogged soil condition in the natural wetland that favored the growth and decomposition of macrophytic plants. There was fluctuating water condition in the restored wetland. Sahrawat (2004) reported that there is preferential accumulation of organic matter in waterlogged soils compare to well-drained soils. Additionally, the less dense vegetation cover may have also contributed to a reduction in the organic matter of the restored. McGeehan (2012) reported that the humus content of a soil is dependent primarily on the quantity of plant material per unit area that reaches the soil and the rate of decomposition. It is also possible that OM could have been lost due to the grading and scraping of surface soil horizons that occurred during the course of restoration to fill ditches and create microtopography.

Although, Nitrogen $(\mathrm{N})$ and Phosphorus $(\mathrm{P})$ were relatively higher in the restored wetland than the natural wetland, the concentrations of $\mathrm{N}$ and $\mathrm{P}$ fell within the same ranges. The source of $\mathrm{N}$ and $\mathrm{P}$ could have been from extra inputs from fertilizers in agricultural fields adjacent to the restored wetland and pollution runoff from a garbage collection point nearby. This was contrary to a study by MorenoMateos et al. (2012) that discovered Nitrogen storage remained significantly lower in restored wetlands for 30 years after the wetlands were restored or created. Similarly, results from studies by Lawrence and Schlesinger (2001) and Smil (2000) found that total phosphorus decreased only slightly in restored or created wetlands and did not show significant differences with reference wetlands. They attributed the lack of variation in phosphorus to more conservative cycling by phosphorus (lack of exchange with the atmosphere). 
Kunan Brewer Vesselly et al.

\section{Management Implications and Conclusions}

In this study we found unimpressive nutrient removal rates for $\mathrm{NH}_{4}-\mathrm{N}, \mathrm{NO}_{3}-\mathrm{N}, \mathrm{TN}, \mathrm{SRP}$ and TP in a restored wetland monitored over one period of wet and dry season in Wakiso district, Uganda. But there was little water quality benefits observed when nutrient fluxes were calculated across the seasons. The retention time in the wetland was in a matter of days making single rain event to move water through the wetland in a matter of hours thus reducing the ability of the wetland to retain and transform nutrients especially in the wet season. The small size of the wetland coupled with additional $\mathrm{P}$ and $\mathrm{N}$ inputs from soil also contributed to the low nutrient removal rates. Soil properties in the restored wetland were found to be in similar ranges when comparison was made with properties of soil in a natural wetland with slight increases observed for $\mathrm{N}$ and $\mathrm{P}$ in the restored wetland. Soil results presented in this study should be treated with caution as soil assessment was not comprehensive and data collected were not sufficient to allow for speculation on restored wetland soil development. Soil data collected was for the purpose of understanding water nutrient behavior.

The monitoring of the restoration should consider management activities like periodic harvesting of shoots, distribution of water throughout the system, invasive species removal as well as the production and multiplication of macrophytic plants especially Cyperus papyrus in order to facilitate better removal capabilities. This study forms a baseline for understanding the ecology of restored wetlands in Uganda and will be helpful to policy makers, technicians and opinion leaders in designing future restoration projects.

\section{Acknowledgements}

This work was supported by the West Africa Agricultural Productivity Program capacity building initiative for the Liberian Ministry of Agriculture. The authors thank Kizza Charles Luswata for helping with soil assessment and Mr. Jean Jacque Bagalwa for assisting with water sampling. The management of the Kawanda Secondary School is also appreciated for its cooperation throughout the study period.

\section{References}

Aldous A, McCormick P, Ferguson C, Graham S, Craft C (2005) Hydrologic regime controls soil phosphorus fluxes in restoration and undisturbed wetlands. Restor Ecol 13:341-7.

APHA (1998) Standard Methods for the Examination of Water and Wastewater. 20th ed.,

American Public Health Association, Washington, D.C.

Braskerud BC (2002) Factors affecting nitrogen retention in small constructed wetlands treating agricultural non-point source pollution. Ecol Eng 18:351-70.

Bridgham SD and Richardson CJ (1993) Hydrology and nutrient gradients in North Carolina peatlands. Wetlands 13: 207-218.

Cabezas A, Garcia M, Gallardo B. Gonzalez, E, Gonzalez-Sanchis M, Comin FA (2009) The

effect of anthropogenic disturbance on the hydrochemical characteristics of riparian wetlands at the middle Ebro River (Spain). Hydrobiologia, 617(1): 101-116.

Charts MSC (1994). New Windsor. New York: Macbeth.

Davidson, NC (2014) How much wetland has the world lost? Long-term and recent trends in global wetland area. Mar. Freshw. Res. 65, 934.

Duan W, He B, Nover D, Yang G, Chen W, Meng H, Zou S, Liu C (2016) Water Quality Assessment and Pollution Source Identification of the Eastern Poyang Lake Basin Using Multivariate Statistical Methods. Sustainability, 8, 133.

Effendi H (2016) River water quality preliminary rapid assessment using pollution index. Procedia Environ. Sci., 33, 562-567. 
Kunan Brewer Vesselly et al.

Fink DF, Mitsch WJ (2007) Hydrology and nutrient biogeochemistry in a created river diversion oxbow wetland. Ecol Eng., 30:93-102.

Fink DF, Mitsch WJ (2004) Seasonal and storm event during nutrient removal by a created wetland in an agricultural watershed. Ecol Eng., 23:313-25.

Jahn R, Blume H, Asio V, Spaargaren O, Schad P (2006). Guidelines for Soil

Description. FAO, Rome.

Jiang X, Xu S, Liu Y, Wang X (2015) River ecosystem assessment and application in ecological restorations: A mathematical approach based on evaluating its structure and function. Ecol. Eng., $76,151-157$.

Jordan TE, Whigham DF, Hofmockel KH, Pittek MA (2003) Nutrient and sediment removal by a restored wetland receiving agricultural runoff. J Environ Qual., 32:1534-47.

Kansiime F, Kateyo E, Oryem-Origa H, Mucunguzi P (2007) Nutrient status and retention in

Pristine and disturbed wetlands in Uganda: Management implications. Wetlands Ecology and Management, 15(6): 453-467.

Khan SJ, Deere D, Leusch FD, Humpage A, Jenkins M, Cunliffe D (2015) Extreme weather events: Should drinking water quality management systems adapt to changing risk profiles? Water Res., 85, 124-136.

Khan K, Lu Y, Khan H, Zakir S, Khan S, Khan AA, Wei L, Wang T (2013) Health risks associated with heavy metals in the drinking water of Swat, northern Pakistan. Journal of Environmental Science, 25(10): 2003-2013.

Kirk JA, Wise WR, Delfino JJ (2004) Water budget and cost-effectiveness analysis of wetland

restoration alternatives: A case study of levy prairie, Alachua County, Florida. Ecological Engineering, 22(1): 43-60.

Kovacic DA, Twait RM, Wallace MP, Bowling JM (2006) Use of created wetlands to improve water quality in the Midwest-Lake Bloomington case study. Ecol Eng., 28:258-70.

Krause S, Jacobs J, Voss A, Bronstert A, Zehe E (2008) Assessing the impact of changes in landuse and management practices on the diffuse pollution and retention of nitrate in a riparian floodplain. Science of the Total Environment, 389(1): 149-164.

Kusler JA and Kentula ME (1990) Executive Summary. In: Wetland Creation and Restoration: The Status of the Science. Island Press, Washington, DC, USA, pp. xvii-xxv.

Kyambadde J, Kansiime F, Gumaelius L, Dalhammar G (2004) A comparative study of Cyperus

papyrus and Miscanthidium violaceum-based constructed wetlands for wastewater treatment in a tropical climate. Water Research, 38(2): 475-485.

Landon, JR (1991) Booker tropical soil manual: A handbook for soil survey and agricultural land

evaluation in the tropics and subtropics. Routledge.

Lawrence D, Schlesinger WH (2001) Changes in soil phosphorus during 200 years of shifting cultivation in Indonesia. Ecology, 82: 2769-2780.

Lu X (2008) Chinese Wetlands and Wetlands Study. Shijiazhuang: Hebei Science \& Technology Press, $1-10$.

McCauley LA, Jenkins DG, Quintana-Ascencio PF (2013) Isolated wetland loss and degradation over two decades in an increasingly urbanized landscape. Wetlands, 33(1): 117-127.

McGeehan SL (2012) Impact of waste materials and organic amendments on soil properties

and vegetative performance. Applied and Environmental Soil Science, 2012, 1-11.

Millennium Ecosystem Assessment (2005) Ecosystems and Human Well-Being: Synthesis. Island Press, Washington, DC.

Mitsch WJ, Gosselink, JG (2015). Wetlands, Fifth ed. Wiley.

Mitsch WJ, Day JW, Gilliam JW, Groffman PM, Hey DL, Randall GW, Wang NM (2001) Reducing nitrogen loading to the Gulf of Mexico from the Mississippi River Basin: strategies to counter a persistent ecological problem. Bioscience, 51:373-88.

Mitsch WJ, Day JW, Zhang L, Lane RR (2005) Nitrate-nitrogen retention in wetlands in the Mississippi river basin. Ecol Eng., 24:267-78.

Mitsch WJ, Bernal B, Hernandez ME (2015) Ecosystem services of wetlands. Int. J. Biodivers. Sci. Ecosyst. Serv. Manag. 11.

Mitsch WJ, Wu XY, Nairn RW, Weihe PE, Wang NM, Deal R, Boucher CE (1998) Creating and restoring wetlands - a whole ecosystem experiment in self-design. Bioscience, 48:1019-30. 
Kunan Brewer Vesselly et al.

Moreno D, Pedrocchi C, Comín FA, García M, Cabezas A (2007) Creating wetlands for the

improvement of water quality and landscape restoration in semi-arid zones degraded by intensive agricultural use. Ecological Engineering, 30(2):103-111.

Moreno-Mateos D, Power ME, Comín FA, Yockteng R (2012) Structural and functional loss in

restored wetland ecosystems. PLoS Biology, 10(1), e1001247.

Okalebo J, Gathua K, Woomer P (2002). Laboratory methods of plant and soil analysis: A

working manual. TSBF-UNESCO, Nairobi.

Okurut TO, Rijs GBJ, van Bruggen JJA (1999) Design and performance of experimental constructed wetlands in Uganda, planted with Cyperus papyrus and Phragmites mauritianus. Water Sci Technol., 40(3): 265-71.

Raisin GW, Mitchell DS, Croome RL (1997) The effectiveness of a small constructed wetland in ameliorating diffuse nutrient loadings from an Australian rural catchment. Ecol Eng., 9:19-35.

Reddy KR, DeLaune RD (2008) Biogeochemistry of wetlands: science and applications. Boca Raton, FL: CRC Press.

Reinelt LE, Horner RR (1995) Pollutant removal from stormwater runoff by palustrine wetlands based on comprehensive budgets. Ecol Eng., 4:77-97.

Sahrawat K (2004) Ammonium production in submerged soils and sediments: The role of

Reducible iron. Communications in soil science and plant analysis, 35(3-4), 399-411.

Smil V (2000) Phosphorus in the environment: natural flows and human interferences. Annu Rev Energ Env., 25: 53-88.

Stolt MH, Genthner MH, Daniels WL, Groover VA, Nagle S, Haering KC (2000) Comparison of soil and other environmental conditions in constructed and adjacent palustrine reference wetlands. Wetlands, 20: 671-683.

Uganda Bureau of Statistics, UBOS (2014) Statistical Abstract. Kampala, Uganda.

Uganda Bureau of Standard, UNBS Available from: https://unbs.go.ug/newshighlights.php?news=107\&read [cited July 18, 2019]

Van Dijk J, Stroetenga M, Bos L, Van Bodegom PM, Verhoef HA, Aerts R (2004) Restoring natural seepage conditions on former agricultural grasslands does not lead to reduction of organic matter decomposition and soil nutrient dynamics. Biogeochemistry, 71:317-37.

Verhoeven JTA, Arheimer B, Yin CQ, Hefting MM (2006) Regional and global concerns over wetlands and water quality. Trends Ecol Evol., 21:96-103.

Vymazal J (2007) Removal of nutrients in various types of constructed wetlands. Science of the Total Environment, 380(1-3): 48-65.

Wang Z, Wu J, Madden M, Mao D (2012) China's Wetlands: Conservation Plans and Policy Impacts. Ambio, 41, 782-786.

Wang H, Sun L, Liu Z, Luo Q (2017) Spatial distribution and seasonal variations of heavy metal contamination in surface waters of Liaohe River, Northeast China. Chinese Geographical

Science, 27(1): 52-62

Whitehead PG, Wilby RL, Butterfield D, Wade, AJ (2006) Impacts of climate change on in-stream nitrogen in a lowland chalk stream: an appraisal of adaptation strategies. Science of the Total Environment, 365(1-3): 260-273.

World Health Organization (2001) Water Quality: Guidelines, Standards and Health: Assessment of risk and risk management for water-related infectious disease. (L. Fewtrell \& J. Bartram, eds). IWA Publishing, London, UK

Zedler JB (2003) Wetlands at your service: reducing impacts of agriculture at the watershed scale. Front Ecol Environ., 1:65-72. 